\title{
Oligaemia, Renal Failure, and Jaundice Associated with Acute Pustular Psoriasis
}

\author{
DAVID J. WARREN, R. J. WINNEY， G. W. BEVERIDGE
}

British Medical fournal, 1974, 2, 406-408

\section{Summary}

An episode of acute pustular psoriasis in a middle-aged man was associated with cholestatic jaundice and followed by acute tubular necrosis. It is suggested that renal failure was due to oligaemia after the loss of albumin into and from the skin. Fluid balance, central venous pressure, and arterial blood pressure should be monitored in patients with acute pustular psoriasis.

\section{Introduction}

Systemic manifestations may attend many skin diseases. In particular, erythroderma may cause serious disorders of body fluid and cardiovascular homeostasis (Shuster, 1971). We describe here the development of jaundice and acute tubular necrosis in a patient with acute pustular psoriasis, and his recovery.

\section{Case Report}

A 55-year-old man had a 15 -year history of chronic psoriasis, which had been generally well controlled by local applications of dilute steroid or Alphosyl (coal tar and Allantoin) preparations. Occasionally the rash was extensive, but the patient had never been treated with oral corticosteroids or methotrexate.

Four days before admission to hospital, at a time when his psoriasis was stable, his skin became irritable and hot with extensive reddening. Though in bed in a warm room he felt cold. During the next three days the skin became tender, and large areas of pustulation developed. Subsequently there was widespread peeling of the skin, and crusting developed on the face and neck.

On admission to hospital there was generalized cutaneous erythema and scleral jaundice. There was dense crusting around the mouth and nose, spreading on to the neck. Large areas of stratum corneum were peeling from the trunk, leaving an exudative surface. Small subcorneal pustules, a few millimetres in diameter, were seen at the margins of the exudative areas. The lymph nodes in the axillae and groins were enlarged, and there was moderate ankle oedema. His temperature was $38.4^{\circ} \mathrm{C}$, pulse rate 95 beats $/ \mathrm{min}$., and arterial blood pressure $170 / 95$ $\mathrm{mm} \mathrm{Hg}$. Blood urea was $24 \mathrm{mg} / 100 \mathrm{ml}$ and the electrolytes were normal. Haemoglobin was $14.6 \mathrm{~g} / 100 \mathrm{ml}$ and W.B.C. $18,600 / \mathrm{mm}^{3}$, with a predominance of polymorphonuclear leucocytes. The liver function tests showed bilirubin $5.9 \mathrm{mg} / 100 \mathrm{ml}$, serum alanine aminotransferase (SGPT) $182 \mathrm{IU} / 1$. , and alkaline phosphatase $40 \mathrm{~K} . \mathrm{A}$. units $/ 100 \mathrm{ml}$. Total plasma protein concentration was $5.9 \mathrm{~g} / 100 \mathrm{ml}$, of which $3.2 \mathrm{~g} / 100 \mathrm{ml}$ was albumin. The plasma uric acid concentration was $7 \cdot 1 \mathrm{mg} / 100 \mathrm{ml}$ (normal range $2-7 \mathrm{mg} / 100 \mathrm{ml}$ ), and calcium was $7 \cdot 7 \mathrm{mg} / 100 \mathrm{ml}$ (normal range $8 \cdot 5-10.5 \mathrm{mg} / 100 \mathrm{ml}$ ).

After the patient's admission to hospital the skin lesion began to improve, but there was progressive deterioration of haemodynamic, renal, and hepatic functions. Selected biochemical and haemodynamic observations made during the course of the illness are shown in the chart.

During the first five days in hospital the pustular component of the skin rash subsided though cutaneous erythema and oedema persisted.

University of Edinburgh, Royal Infirmary, Edinburgh EH3 9YW DAVID J. WARREN, D.PHIL., M.R.C.P., Lecturer in Medicine ROBIN J. WINNEY, M.B., M.R.C.P., Registrar at Medical Renal Unit G. W. BEVERIDGE, M.B., F.R.C.P., Consultant Dermatologis
By the fifth day after admission the W.B.C. had risen to $34,600 / \mathrm{mm}^{3}$, of which $87 \%$ were polymorphonuclear leucocytes, and the E.S.R. had risen to $132 \mathrm{~mm}$ in one hour. The blood pressure fell to $105 / 60$ $\mathrm{mm} \mathrm{Hg}$, and central venous pressure (C.V.P.) measurements, begun on the fifth day, were consistently -2 to $-4 \mathrm{~cm} \mathrm{H}_{2} \mathrm{O}$. These haemodynamic changes were associated with a progressive fall in urine output to less than $20 \mathrm{ml} / 24 \mathrm{hr}$, and rises in blood urea and plasma creatinine to $220 \mathrm{mg}$ and $8.2 \mathrm{mg} / 100 \mathrm{ml}$ respectively. The plasma sodium concentration remained around $140 \mathrm{mmol} / \mathrm{l}$. The plasma albumin concentration fell from $3.2 \mathrm{~g}$ to $1.8 \mathrm{~g} / 100 \mathrm{ml}$ and the plasma calcium concentration to $7.5 \mathrm{mg} / 100 \mathrm{ml}$. The plasma uric acid concentration rose to $22 \mathrm{mg} / 100 \mathrm{ml}$. The plasma bilirubin concentration reached a maximum of $10.4 \mathrm{mg} / 100 \mathrm{ml}$ though the SGPT fell from its admission value to $49 \mathrm{IU} / 1$., and the alkaline phosphatase fell to 29 K.A. units $/ 100 \mathrm{ml}$.

In the course of the fifth and sixth days in hospital the patient was given 2 units of whole blood and 3,200 ml of plasma protein solution (containing $4.3 \mathrm{~g}$ total protein $/ 100 \mathrm{ml}$, of which $92 \%$ was albumin, and $130-150 \mathrm{mmol} / \mathrm{l}$. of sodium) in an attempt to raise the blood pressure and C.V.P., without effect. By the sixth day the blood urea had risen to $252 \mathrm{mg} / 100 \mathrm{ml}$, and haemodialysis was carried out using a Travenol machine and Ultra-Flo II coil dialyser. A further three haemodialyses were needed before the blood urea began to fall spontaneously on the 15th day. During this period exudation from the skin ceased and gave way to erythema and oedema, associated with extensive exfoliation and desquamation of the skin of the hands and feet. The W.B.C. fell gradually to $20,000 / \mathrm{mm}^{3}$, but the E.S.R. remained raised at $138 \mathrm{~mm}$ in one hour. The blood pressure rose slowly to $130 / 60 \mathrm{~mm} \mathrm{Hg}$ though the C.V.P. remained below zero in spite of the fact that a further $5,200 \mathrm{ml}$ of plasma protein solution had been given between the sixth and 15th day. Urine output rose from $10 \mathrm{ml}$ to $3,685 \mathrm{ml} / 24 \mathrm{hr}$ and the urinary sodium excretion rose to $33 \mathrm{mmol} / 24 \mathrm{hr}$. The plasma albumin concentration rose to $3.0 \mathrm{~g} /$

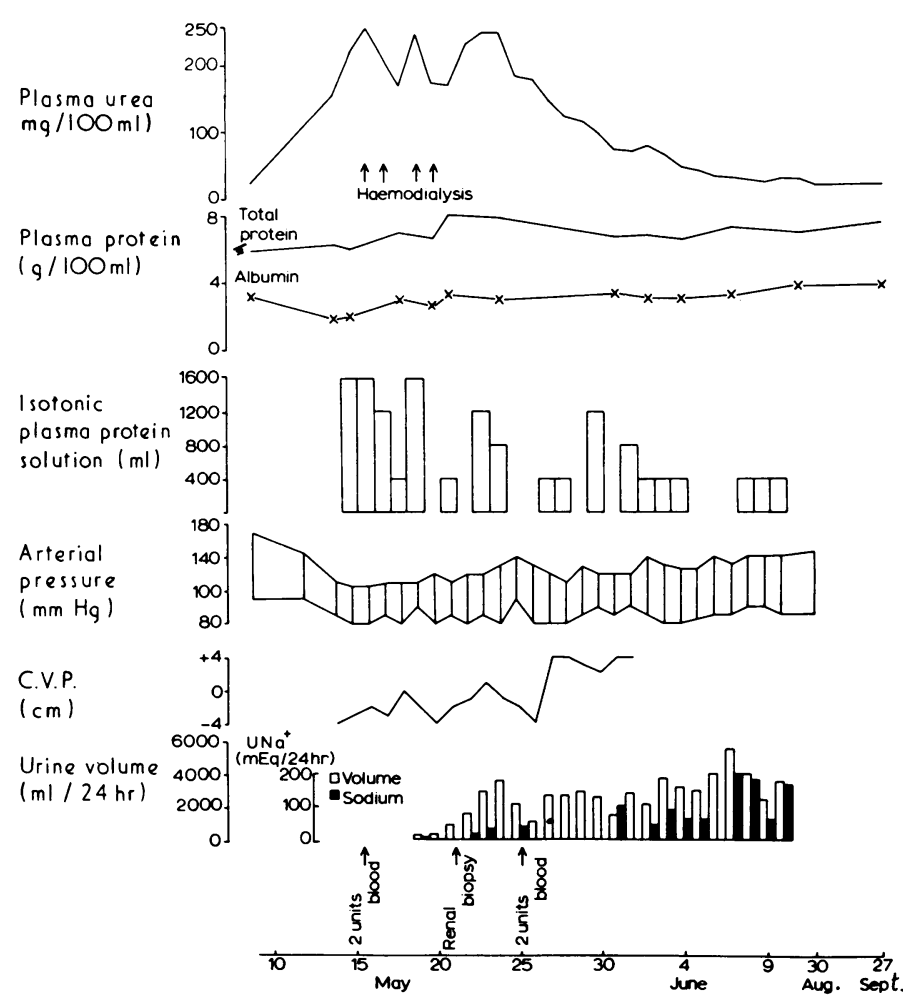

Development of and recovery from acute renal failure in a man with acute pustular psoriasis. C.V.P. = Central venous pressure. 
$100 \mathrm{ml}$ and the plasma calcium to $8.5 \mathrm{mg} / 100 \mathrm{ml}$. The plasma uric acid concentration fell to $13 \mathrm{mg} / 100 \mathrm{ml}$. The results of liver function tests began to improve, the plasma bilirubin falling to $2.9 \mathrm{mg} / 100 \mathrm{ml}$, SGPT to $19 \mathrm{IU} / 1$, and the alkaline phosphatase to $23 \mathrm{~K}$.A. units/ $100 \mathrm{ml}$.

From the 15th day onwards a progressive fall in blood urea was associated with rapid resolution of cutaneous oedema though extensive exfoliation continued for two weeks and had not completely disappeared by the time of discharge from hospital. During this recovery phase there was marked improvement in haemodynamic function. The blood pressure rose to $145 / 70 \mathrm{~mm} \mathrm{Hg}$, and it was possible to stop recordings of C.V.P. once consistently positive values had been obtained. The blood urea fell to normal, and urine output reached a maximum of $5,500 \mathrm{ml} / 24 \mathrm{hr}$. The urinary sodium excretion rate increased rapidly to $200 \mathrm{mmol} / 24 \mathrm{hr}$ soon after the C.V.P. had become consistently positive and resolution of cutaneous oedema and erythema had occurred. During this period a further $5,500 \mathrm{ml}$ of plasma protein solution was given in an attempt to maintain the blood pressure.

By the time of discharge the results of liver function tests were all within normal limits; the W.B.C. count had fallen to $7,000 / \mathrm{mm}^{3}$ and the E.S.R. to $28 \mathrm{~mm}$ in one hour.

\section{MISCELLANEOUS INVESTIGATIONS}

Stool, skin, nose, throat, ear, sputum, and daily blood cultures were all negative. Initial urine cultures showed a growth of Escherichia coli though a bladder catheter had been inserted when the patient became oliguric soon after admission to hospital. Examination of paired sera showed no evidence of infection with influenza $\mathbf{A}$ or B, adenovirus, psittacosis, respiratory synctial virus, Mycoplasma pneumoniae, $\mathbf{Q}$ fever, leptospirosis, or brucellosis. An immunoelectrophoresis test for Australia antigen and antibody was negative.

Chest $x$-ray examination showed left ventricular prominence, but pulmonary oedema was never observed. Liver scintography was normal, and showed the spleen to be of normal size. The results of smooth muscle and mitochondrial antibody tests were negative, and the E.C.G. was normal. Serum electrophoresis showed a diffuse increase in alpha globulin, alpha $a_{2}$-globulin, and gammaglobulin. Urinary protein concentration was less than $30 \mathrm{mg} / 100 \mathrm{ml}$ on three occasions. The antinuclear factor test was negative. Examination by light miscrocopy of a renal biopsy showed acute tubular necrosis. Immunofluorescent studies showed no specific reaction to the immunoglobulins $G, A, M$, $\mathrm{D}$, complement (C3 and C4), or fibrin or fibrinogen.

\section{Discussion}

This patient illustrates the life-threatening complications which may accompariy acute pustular psoriasis. The degree of hepatic failure, oligaemia, and renal failure together constituted a unique series of complications in this disease.

Though the patient had pre-existing psoriasis the explosive onset and short duration of the pustular phase was in keeping with the exanthematous type of pustular psoriasis (Baker and Ryan, 1968). Possible provocative factors were considered since they might have been implicated in the development of hepatic and renal failure. There was no history of drug ingestion and no evidence of bacterial or viral infection before admission. Systemic corticosteroids had never been given and though dilute corticosteroid ointment had been used it had not been withdrawn suddenly. Hypocalcaemia has in the past been considered to be capable of inducing an acute episode of pustular psoriasis, but it is now believed to be secondary to the hypoalbuminaemia which occurs in this disease (Braverman et al., 1972).

\section{PATHOPHYSIOLOGY OF ACUTE TUBULAR NECROSIS IN PSORIASIS}

The rise in blood urea which occurred in our patient was associated with hypoalbuminaemia, hypotension, and low C.V.P. The urine volume fell to zero within five days. During the period which elapsed before the blood urea returned to normal 13,900 $\mathrm{ml}$ of isotonic plasma protein solution was given. Of this total volume $8,800 \mathrm{ml}$ was given before the C.V.P. became con- sistently positive. The total volume of plasma protein solution given to this patient during the course of his illness was more than three times the estimated normal plasma volume.

We think that there was massive leakage of plasma proteins from capillaries both into the skin, producing skin oedema, and, to a lesser extent, from the skin in the form of an exudate. The consequent oligaemia caused renal ischaemia of such severity that acute tubular necrosis developed. It is likely that these effects of oligaemia were further potentiated by a large rise in skin blood flow.

Measurements of plasma volume using ${ }^{51} \mathrm{Cr}$ erythrocytes in patients with erythroderma showed that in most the plasma volume was increased (Shuster and Marks, 1970), probably because of cutaneous vasodilatation. In the clinical assessment of patients with severe erythroderma such results may be misinterpreted unless they are considered together with prevailing haemodynamic measurements. The blood contained within the hyperdynamic cutaneous circulation may not participate in reflex circulatory adjustments to changes in circulating volume so that hypotension and a fall in C.V.P. may exist at a time when measurements with ${ }^{51} \mathrm{Cr}$ suggest that hypervolaemia is present. Thus "effective plasma volume" may be low when "apparent plasma volume" is high. By analogy with the measurements of Shuster and Marks it is likely that "apparent plasma volume" in our patient was high though the haemodynamic observations clearly indicated a fall in "effective plasma volume." It therefore follows that therapeutic efforts to maintain "effective plasma volume" should be monitored by reference to C.V.P. and blood pressure rather than to plasma volums.

Increased capillary permeability to albumin occurs in several dermatoses, including psoriasis (Marks and Shuster, 1966) though gross oedema is unusual. Recent observations with electron microscopes have shown that abnormal vessels are found in the papillae and in the dermis close to the basal cell layer of the skin and that gaps occur between the endothelial cells of these vessels (Braverman et al., 1972). Since erythrocytes and leucocytes were seen to move through the gaps between the endothelial cells it seems likely that albumin may also be lost from the circulation by this route. Some of this albumin may be lost as exudate, and Pegum (1951) has estimated that this may amount to 4-9 $\mathrm{g} /$ day.

Possibly impaired hepatic synthesis of albumin contributed to hypoalbuminaemia in our patient. The failure of large volumes of plasma protein solution to restore blood pressure and C.V.P. suggests that this factor was of minor importance in producing the observed haemodynamic abnormalities.

\section{LIVER DISEASE IN PSORIASIS}

Several abnormalities in liver function have been noted in association with skin disease (Bauer, 1953; Tickner and Basit, 1960; Shuster and Wilkinson, 1963), including a rise in alkaline phosphatase activity (Braverman et al., 1972; Copeman and Bold, 1965). The results of histological examination of the liver in several patients with erythroderma have usually been normal (Butterworth, 1936; Pegum, 1951; Shuster and Wilkinson, 1963) though pericholangitis has been seen in association with acute pustular psoriasis (Shelley, 1967). The high alkaline phosphatase activity and bilirubin concentration observed in our patient would be consistent with an episode of cholangitis though the effects of oligaemia on liver function seem likely to have contributed to the overall picture.

\section{URIC ACID METABOLISM}

The degree of increase in uric acid which occurs in psoriasis may be related to the extent of the rash (Eisen and Seegmiller, 1961), and attacks of gout have occasionally been precipitated by acute episodes of erythroderma (Kaplan and Klatskin, 1960). The very high level seen in the present case was probably due to the combined effects of increased nucleotide metabolism and decreased 
renal clearance of uric acid. At this concentration $(22 \mathrm{mg} /$ $100 \mathrm{ml}$ ) of uric acid there would be a significant risk of further renal damage due to precipitation of uric acid crystals within the renal tubules.

This case emphasizes the severity of the systemic disorders which may be associated with skin disease.

Requests for reprints should be addressed to Dr. D. J. Warren at the Medical Renal Unit, Royal Infirmary, Edinburgh EH3 9YW.

\section{References}

Baker, H., and Ryan, T. J. (1968). British fournal of Dermatology, 80, 711 ,
Bauer, F. (1953). Australian fournal of Dermatology, 2, 69.

Braverman, I. M. Cohen, I. and O'Keefe, E. (1972) Archives of Dermatology, 105, 189

Butterworth, T. (1936). Archives of Dermatology and Syphology, 34, 676.

Copeman, P. W. M., and Bold, A. M. (1965). Proceedings of the Royal Society of Medicine, $\mathbf{5 8}, \mathbf{4 2 5}$

Eisen, A. Z., and Seegmiller, J. E. (1961). Journal of Clinical Investigation 40,1486 .

Kaplan, H., and Klatskin, G. (1960). Yale Fournal of Biology and Medicine, $32,335$.

Marks, J., and Shuster, S. (1966). British Medical fournal, 2, 88.

Pegum, J. S. (1951). Guy's Hospital Reports, 100, 304

Shelley, W. B (1967) Fournal of the American Medical Association, 201, 1009. Butterworths.

Shustemic Effects of Skin Disease. London, Heineman Medical Books.

Shuster, S., and Wilkinson, P. (1963). British fournal of Dermatology, 75, 344

Shuster, S., and Wilkinson, P. (1963). British fournal of Dermatology, 75, 344.
Tickner, A., and Basit, A. (1960). British fournal of Dermatology, 72, 138.

\title{
Thyrotoxicosis and Giant-Cell Arteritis
}

\author{
R. D. THOMAS, D. N. CROFT
}

British Medical fournal, 1974, 2, 408-409

\section{Summary}

In a retrospective survey we found that five (8.5\%) out of 59 women with giant-cell arteritis had a history of thyrotoxicosis. This was significantly higher than in a control group of patients. Giant-cell arteritis and thyrotoxicosis occurred simultaneously in two cases. Knowledge of this association is of clinical use and is further evidence for an immunological basis for giant-cell arteritis.

\section{Introduction}

We have recently seen three patients with giant-cell arteritis, of whom one had thyrotoxicosis and two had primary hypothyroidism. This was of interest as a clinical observation and in relation to the aetiology of these disorders. We therefore carried out a retrospective survey to determine whether there was an association between thyroid dysfunction and giant-cell arteritis.

\section{Patients and Methods}

The notes of all patients with giant-cell arteritis who attended the hospital from 1957 to 1972 were examined for a history of thyrotoxicosis and primary hypothyroidism. These diagnoses were accepted when confirmed by radioiodine uptake and measurement of blood thyroidal hormones.

There were 101 cases of giant cell arteritis. In 58 of them the diagnosis had been confirmed by a temporal artery biopsy. In 19 of the remaining 43 no biopsy had been performed because there was no doubt of the diagnosis and in 24 the biopsy findings were negative. All of the 43 patients in whom the diagnosis had not been confirmed by biopsy had a typical history (Hamilton et al., 1971), a raised erythrocyte sedimentation rate, and had responded well to treatment with systemic corticosteroids. It is well known that the temporal artery may appear normal in a single biopsy examination in patients with

giant-cell arteritis (Birkhead et al., 1957), so we had little hesitation in including in our study the patients in whom the biopsy findings had been negative. We have called the patients with biopsy evidence of giant-cell arteritis the "confirmed" group, and those without biopsy evidence the "clinical" group. There were 32 women and 26 men in the confirmed group and 27 women and 16 men in the clinical group. The differences in age and erythrocyte sedimentation rate between the two groups of patients were not significant, and the mean age of all patients was 70.3 years.

Because there were no cases of thyroid dysfunction among the men studied we excluded men from the control group. This comprised 200 women aged 50 years or more (mean age 70.6 years) who had been consecutive acute admissions to hospital with pneumonia. The prevalence of thyrotoxicosis and hypothyroidism among them was assessed by the same criteria as in the patients with giant-cell arteritis.

\section{Results}

A history of thyrotoxicosis was found in three out of 32 women with confirmed giant-cell arteritis and in two out of the 27 women with clinical giant-cell arteritis-an overall prevalence $8.5 \%$. There were two $(3.4 \%)$ cases of hypothyroidism, both in women. There were no cases of thyrotoxicosis or hypothyroidism in men. Among the 200 controls there were three cases of thyrotoxicosis and four of hypothyroidism-a prevalence of $1.5 \%$ and $2 \%$ respectively.

Therefore in women with giant-cell arteritis the prevalence of thyrotoxicosis was $8.5 \%$ compared with $1.5 \%$ in the control group. The difference was significant $(P<0.017)$. Because of the small numbers Fisher's exact test for comparing two proportions in a $2 \times 2$ table was used for the analysis. There was no significant difference in the prevalence of hypothyroidism. If we discount the case that drew our attention to the association the prevalence becomes $6.8 \%$, which is also significant $(P<0.05)$.

Arteritis followed thyrotoxicosis at intervals of four and a half, six, and 15 years respectively in three cases, and in two the diseases occurred simultaneously. These two, described below, are of particular interest.

Case 1.-A 74-year-old woman presented with a two-year history of episodic muscular weakness and tremor associated with temporal and occipital headaches, scalp tenderness, and blurred vision. She appeared thyrotoxic and had a score of 21 on the Wayne Clinical Index (Crooks et al., 1959). The temporal arteries 